\title{
Cooperation between Major Histocompatibility Complex Mismatched Mononuclear Cells from a Human Chimera in the Production of Antigen-specific Antibody
}

\author{
Maria Grazia Roncarolo, Jean-Louis Touraine, and Jacques Banchereau \\ Transplantation and Immunobiology Unit, Institut Nationale de la Santé et de la Recherche Medicale U. 80, Hôpital E. Herriot, \\ 69374 Lyon Cedex 8, France; and Laboratory for Immunological Research, Unicet, 69570 Dardilly, France
}

\begin{abstract}
Fetal liver and thymus transplantation can be successfully employed for the treatment of severe combined immunodeficiency disease. In virtually all cases, donor and recipient cells are HLA mismatched. In a patient suffering from a severe combined immunodeficiency disease, full immunological reconstitution was obtained after fetal liver and thymus transplantation. HLA typing revealed that the patient's $T$ cells were of donor origin, while the $B$ cells and monocytes were of host origin. Despite this complete HLA mismatch, the patient was found to mount a subnormal to normal antibody response in vivo. This finding is in contrast with the concept that antigen recognition by $T$ cells is major histocompatibility complex (MHC) restricted. To define the mechanism responsible for this in vivo antibody response, antibody production by peripheral blood mononuclear cells from the patient was tested in vitro after in vivo booster. The in vitro anti-tetanus toxoid antibody production was similar to that of the control group. In addition, specific proliferative responses to tetanus toxoid were obtained. Immunoglobulin allotype determination showed that antibodies were synthetized by host $B$ cells. The results of the present study indicate that transplanted $T$ lymphocytes and recipient cells cooperate despite complete HLA mismatch.
\end{abstract}

\section{Introduction}

Severe combined immunodeficiency (SCID) ${ }^{1}$ can be treated by bone marrow transplantation (1). As an alternative, especially when no histocompatible marrow donor is available, fetal liver and thymus transplantation (FLTT) can be successfully em-

Address correspondence to Dr. Roncarolo, The Children's Hospital, Istituto di Clinica Pediatrica, Division of Immunology, Piazza Polonia 94, 10126 Turin, Italy.

Received for publication 12 March 1985 and in revised form 17 September 1985.

1. Abbreviations used in this paper: $\mathrm{Ab}$, antibody; $\mathrm{Ag}$, antigen; $\mathrm{APC}$, antigen presenting cells; ELISA, enzyme-linked immunosorbent assay; FLTT, fetal liver and thymus transplantation; Gm, immunoglobulin G heavy chain allotypes; $\mathrm{Km}$, immunoglobulin $\mathrm{K}$ light chain allotypes; MHC, major histocompatibility complex; PBMNC, peripheral blood mononuclear cells; PBS-Tween, phosphate-buffered saline containing 0.05\% Tween 20; PWM, pokeweed mitogen; SCID, severe combined immunodeficiency; TT, tetanus toxoid.

J. Clin. Invest.

(C) The American Society for Clinical Investigation, Inc.

0021-9738/86/03/0673/08 \$1.00

Volume 77, March 1986, 673-680 ployed (1). In virtually all cases of FLTT, no attempt at matching donor and recipient is made. As a result, lymphocytes developing from the transplanted stem cells are mismatched with host cells. This situation provides a unique opportunity to study in man the effect of HLA mismatch on in vivo and in vitro cellular cooperation involved in the antigen $(\mathrm{Ag})$ specific antibody $(\mathrm{Ab})$ response.

The induction of specific Ab synthesis by B lymphocytes against thymus-dependent $\mathrm{Ag}$, such as tetanus toxoid (TT), requires $\mathrm{Ag}$ specific $\mathrm{T}$ lymphocytes as well as nonantigen presenting cells (APC). Such accessory cells process complex Ag and, subsequently, present the modified $\mathrm{Ag}$ in an immunogenic form to helper $\mathrm{T}$ cells, which trigger B lymphocytes to produce specific $\mathrm{Ab}$ (2). Ag recognition by helper $\mathrm{T}$ cells is restricted by cell surface molecules encoded by the I region on the $\mathrm{H}_{2}$ complex in mice, or by its human homologue, the HLA-D region (3).

Cooperation between certain $T$ and B lymphocyte subsets is also restricted (4). Although this phenomenon of major histocompatibility complex (MHC) restriction is well established, it remains controversial whether the sharing of HLA class II molecules is an absolute prerequisite for effective cellular interactions. Moreover, the mechanism underlying the commitment to self-restricted MHC specificity remains unclear. Many hypotheses, especially concerning the role of the thymus in commitment to specificity, have been tested using either inbred animal models or in vitro human models (5-8). As yet, no clear consensus view has emerged. We have studied specific $\mathrm{Ab}$ production in a patient suffering from SCID in whom full immunological reconstitution was achieved after FLTT. Despite complete HLA mismatch between donor T cells and host cells, the patient was shown to respond in vivo to TT after immunization (9). This observation suggested, in contrast to the present concept of genetic restriction, the possibility of cellular cooperation across the allogeneic barrier in long-term human chimeras.

The present study was undertaken $(a)$ to define whether antiTT Ab was synthetized by host B cells and not by donor B cells present in the recipient; $(b)$ to exclude a mechanism, present in vivo but not in vitro, which circumvents restriction either by the ability of nonmonocytic Ag presenting cells to interact with donor-derived T lymphocytes (2) or by a nonspecific lymphokine-driven mechanism (10); and (c) to test the hypothesis that in vivo specific $\mathrm{Ab}$ production was due to the cooperation between cells bearing different HLA determinants. Our results show that anti-TT Ab synthesis by host B cells is present in vitro, and results from a cooperation between transplanted $T$ cells and recipient cells. This finding suggests that, in subjects with established chimerism, the $\mathrm{T}$ lymphocyte population can develop recognition for $\mathrm{Ag}$ presented by HLA mismatched monocytes, and can provide the help necessary for $\mathrm{Ab}$ production by allogeneic B cells. 


\section{Methods}

Patient. The clinical course of the patient before and after transplantation has been previously reported (1). $2 \mathrm{yr}$ after transplantation (1978), the patient was given a series of three immunizations with TT at 1-mo intervals. Serum anti-TT Ab was detected after vaccination (9). Two booster immunizations were given in 1979 and 1982, respectively, which resulted in increased serum levels of anti-TT Ab. The patient exhibited a positive delayed hypersensitivity skin reaction to TT.

Controls. All subjects selected for the control group had accurately recorded immunization histories. The range of time since previous booster was from 1 to $5 \mathrm{yr}$. Ab production against TT was studied in nine healthy volunteers consisting of two children of a similar age as the patient and seven adults. Four controls were further tested for an in vitro Ag-specific proliferative response.

Immunizations. The patient and controls received a booster immunization with 40 IU of TT (Institut Merieux, Lyon, France). The patient also received a second immunization after $4 \mathrm{mo}$. Since it has previously been demonstrated $(11,12)$ that in vitro $\mathrm{Ag}$-specific Ig production was maximal 2-4 wk after booster injection, peripheral blood was drawn before and 2 wk after immunization. In addition, in two normal subjects and in the transplanted patient, blood samples were also drawn at 4 or 6 wk post booster.

Allotype determination. Immunoglobulin $\mathrm{G}(\mathrm{IgG})$ heavy chain $(\mathrm{Gm})$ and $\mathrm{K}$ light chain $(\mathrm{Km})$ allotyping was kindly determined by $\mathrm{Dr}$. $\mathrm{L}$. Rivat (Inserm 78, Bois-Guillaume, France) using inhibition of hemagglutination assay (13). Allotype determination was carried out on serum that contained anti-TT-specific $\mathrm{Ab}$ as demonstrated by ELISA.

HLA typing. HLA typing was performed on peripheral blood mononuclear cells (PBMNC), on enriched T cells obtained from a nylon wool column (14), on monocytes isolated by adherence to plastic plates (15), and on an enriched $B$ cell fraction obtained by $T$ cell and adherent cell depletion (14). HLA-DR antigens on T lymphocytes were determined after in vitro incubation with IL-2 (16). HLA typing was carried out by Dr. H. Betuel (Centre De Transfusion, Lyon, France) using a cytotoxicity assay (14).

Cell separations and culture conditions. PBMNC were isolated from heparinized blood by Ficoll-Hypaque gradient centrifugation. Cells were cultured in RPMI-1640 medium (Gibco, Irvine, United Kingdom) supplemented with $2 \mathrm{mM}$ L-glutamine (Gibco), $100 \mathrm{U} / \mathrm{ml}$ penicillin, 100 $\mu \mathrm{g} / \mathrm{ml}$ streptomycin (Gibco) and selected heat-inactivated fetal calf serum (Industrie Biologique Française, Genevilliers, France). Assays for the determination of both total Ig and specific $A b$ production were performed in the presence of various concentrations of TT $(0.05 \mathrm{ng} / \mathrm{ml}$ to $10 \mu \mathrm{g} /$ ml TT, Behring, Marburg, Federal Republic of Germany) or pokeweed mitogen (PWM; Gibco, lot 15K3234) at a final dilution of 1:400 (1 $\mu \mathrm{g} /$ $\mathrm{ml})$ and $1: 100(4 \mu \mathrm{g} / \mathrm{ml})$.

When present in controls, cycloheximide (Sigma Chemical Co., St. Louis, MO) was added at $100 \mu \mathrm{g} / \mathrm{ml}$. Cell culture was carried out in roundbottomed $12 \times 75$-mm plastic tubes (2058, Falcon Labware, Becton-Dickinson \& Co., Oxnard, CA) at $0.5,1$, and $2 \times 10^{6} \mathrm{cells} / \mathrm{ml}$ in a final volume of $0.5 \mathrm{ml}$. Cultures were incubated at $37^{\circ} \mathrm{C}$ in a humidified $\mathrm{CO}_{2}$ incubator $\left(5 \% \mathrm{CO}_{2} /\right.$ air $)$. Supernatants were harvested after $12 \mathrm{~d}$ and assayed for both specific and total Ig by ELISA. All cultures were performed in duplicate. Ag-specific cell proliferation was performed with a range of TT concentrations $(1-50 \mu \mathrm{g} / \mathrm{ml})$. Cultures were carried out in triplicate in flatbottomed microculture plates (Falcon Labware) at $2 \times 10^{6}$ cells $/ \mathrm{ml}$ in a final volume of $0.2 \mathrm{ml}$. Plates were incubated for $6 \mathrm{~d}$ at $37^{\circ} \mathrm{C}$ in a humidified $\mathrm{CO}_{2}$ incubator. Cultures were then labeled overnight with $\left[{ }^{3} \mathrm{H}\right]$ thymidine $(1 \mu \mathrm{Ci} /$ well). Cells were harvested using a multiple sample harvester. Data are expressed as cpm $\left[{ }^{3} \mathrm{H}\right]$ thymidine incorporated.

ELISA. Culture supernatants and serum were screened for specific anti-TT $\mathrm{Ab}$ using an indirect Ab ELISA test. Flatbottomed microtiter plates (Immulon II, Dynatech Laboratories, Inc., Alexandria, VA) were coated at $4^{\circ} \mathrm{C}$ overnight with $200 \mathrm{ng}$ purified TT per well in $0.2 \mathrm{ml}$ of $50 \mathrm{mM}$ carbonate/bicarbonate buffer, $\mathrm{pH}$ 9.6. Plates were subsequently washed four times with phosphate-buffered saline containing $0.05 \%$
Tween 20 (PBS-Tween). $200 \mu l$ of culture supernatants or serum, appropriately diluted in PBS-Tween, were added to wells and incubated for $3 \mathrm{~h}$ at $37^{\circ} \mathrm{C}$. After washing in PBS-Tween, $200 \mu \mathrm{l}$ of alkaline phosphatase conjugated rabbit $\mathrm{Ab}$ directed against either human IgG or IgM (Calbiochem-Behring Corp., La Jolla, CA) was added to each well. After $2 \mathrm{~h}$ incubation at room temperature and four subsequent washings, substrate was added to each well $(1 \mathrm{mg} / \mathrm{ml}$ paranitrophenyl phosphate in $0.9 \mathrm{M}$ diethanolamine buffer, $\mathrm{pH} 9.8$, containing $0.5 \mathrm{mM} \mathrm{MgCl}$ ).

Optical density values for each well were determined using a micro ELISA autoreader (MR 580, Dynatech Laboratories, Inc.). Each supernatant was assayed in duplicate. Each serum was assayed at several dilutions. The dose-response relationship for dilution of serum was linear for all samples within the range 1:250-1:250,000. The amount of antiTT IgG was determined by comparison to a standard curve constructed using a human anti-TT Ig preparation (125 IU $/ \mathrm{ml}$; Gamma T. S. Antitetaniques, Cnts, Lyon, France). The absolute anti-TT Ab concentration of the standard Ig preparation was calibrated using affinity-purified antiTT Ab. All values were calculated in international units per milliliter of TT Ab using the Gamma TS standard, and subsequently converted to absolute units after calibration of the standard (1 ng anti-TT Ab $=5$ $\left.\times 10^{-5} \mathrm{IU}\right)$.

The sensitivity of the ELISA, defined as being equal to the value at a point on the standard assay curve two standard deviation from the mean zero binding value, was $0.1 \mathrm{ng} / \mathrm{ml}$. IgM anti-TT Ab, for which no purified preparation was available, were expressed as arbitrary units per milliliter by comparison with a laboratory standard.

The specificity of the TT Ab determination by ELISA was tested by adding soluble $\mathrm{Ag}$ ( $10 \mu \mathrm{g} / \mathrm{ml}$ or more) to culture supernatants $2 \mathrm{~h}$ before assay. Total IgG and IgM were measured in a similar manner to that already described except that plates were coated with rabbit anti-human $\gamma$-chain or rabbit anti-human $\mu$-chain, respectively (Calbiochem-Behring Corp.). The amount of total Ig was determined by comparison with a standard curve constructed using known amounts of purified IgM and IgG.

Affinity purification of anti-TT Ig standard. Purified TT was dialyzed overnight against $0.1 \mathrm{M} \mathrm{NaHCO}$, pH 8.3 , containing $0.5 \mathrm{M} \mathrm{NaCl}$. The $\mathrm{Ag}$ was then incubated with $\mathrm{CNBr}$-activated Sepharose 4B (Pharmacia Fine Chemicals, Uppsala, Sweden) overnight at $4^{\circ} \mathrm{C}$. Residual active sites were blocked with $0.2 \mathrm{M}$ glycine, $\mathrm{pH}$ 8.0. The absorbent was then washed alternatively with high and low $\mathrm{pH}$ buffer $(0.1 \mathrm{M}$ acetate buffer, $\mathrm{pH} 4$, containing $0.5 \mathrm{M} \mathrm{NaCl}$, followed by coupling buffer, $\mathrm{pH} 8.3$ ). The sample to be purified was diluted in PBS, pH 7.2, then incubated overnight at $4^{\circ} \mathrm{C}$ with end over end rotation. The gel was then packed into a column and unbound material washed out with PBS. Specific elution was carried out using $0.2 \mathrm{M}$ glycine buffer, $\mathrm{pH}$ 2.5. The eluate was immediately neutralized with $1 \mathrm{M}$ Tris, $\mathrm{pH} 7.5$. The concentration of purified IgG, in milligrams per milliliter, was determined by optical density at 280 $\mathrm{nm}$ using the formula: (OD 280)/(1.2). Protein was shown to be IgG by sodium dodecyl sulfate-polyacrylamide gel electrophoresis.

\section{Results}

\section{HLA antigens}

Determination of HLA antigens performed before the transplantation, using PBMNC of the SCID patient and of the parents, revealed that the patient's HLA type was: Aw33, 3; B14, W47; DR4, 5, (16). HLA typing performed again in 1981, 5 yr after transplant, on parent's PBMNC and patient's B cells (Table I) confirmed that the patient's HLA type was: AW33, 3 B14, W47; CW6, W2; DR4, 5. Moreover, it was shown at that time that monocytes expressed the host phenotype with the exception of a small proportion that was weakly positive for DR1 and DR7. In contrast, the $T$ lymphocytes had the donor phenotype: HLA A1, 2; B8, 18; CW7; DR1, 7 (9).

The patient was retyped several times thereafter. In 1983, 7 
Table I. HLA Typing of the FLTT Subject and His Parents

\begin{tabular}{|c|c|c|c|c|}
\hline & HLA locus & HLA locus & HLA locus & HLA locus \\
\hline & A & $\mathrm{C}$ & B & DR \\
\hline \multicolumn{5}{|l|}{ Father* } \\
\hline $\mathbf{a}$ & 1 & W4 & 17 & 7 \\
\hline b & W33 & W6 & 14 & 4 \\
\hline \multicolumn{5}{|l|}{ Mother* } \\
\hline c & 3 & W2 & W47 & 5 \\
\hline d & W26 & W4 & 12 & 1 \\
\hline \multicolumn{5}{|l|}{ Patient* } \\
\hline b & W33 & W6 & 14 & 4 \\
\hline c & 3 & W2 & W47 & 5 \\
\hline \multicolumn{5}{|l|}{ Patient $\ddagger$} \\
\hline $\mathrm{T}$ cells donor & $1-2$ & w7 & $8-18$ & $1-7 \S$ \\
\hline B cells host & W33-3 & W6 & 14-W47 & $4-5$ \\
\hline Monocytes host & W33-3 & & 14-W47 & $4-5$ \\
\hline
\end{tabular}

* HLA genotypes of the family.

$\ddagger$ HLA phenotype of patient $7 \mathrm{yr}$ after the transplant. HLA typing was carried out on enriched cell populations obtained as described in Methods.

$\S$ After in vitro activation and culture with $\mathrm{T}$ cell growth factor.

yr after the transplant, the patient's PBMNC were studied with the ninth workshop antisera and the split chimerism was confirmed. All B lymphocytes and monocytes were shown to be of host origin, whereas the $\mathrm{T}$ lymphocytes were donor derived (Table I). There was no indication of the presence of donor HLA antigens in the monocytes and B cell populations. In contrast, all $\mathrm{T}$ lymphocytes expressed the donor's HLA antigens.

\section{Immunoglobulin allotype}

In order to determine whether the $\mathrm{Ab}$ produced were of donor or host origin, Ig allotyping was carried out in serum from the patient and his parents. The results showed that the patient's Ig had genetic markers compatible with parental Ig allotypic markers (Table II). The patient's genotype consisted of two haplotypes present in the parental pool: $\mathrm{Gm} 3,23,10$, and 11 , corresponding to the father, and $\mathrm{Gml}, 10$, and 11 corresponding to the rare allotype of the mother. No nonparental allotypes could be identified.

\section{Determination of anti-TT antibodies}

Specific anti-TT antibody levels were detected in sera and PBMNC culture supernatants by ELISA. In Fig. 1, a mean ELISA IgG standard curve averaged from 25 experiments is shown. The SD values indicate that good interassay reproducibility was obtained.

As described previously, the absolute quantification of specific IgG was calculated by calibration of the anti-TT standard using an affinity-purified anti-TT IgG. We found that $1 \mathrm{ng}$ of specific anti-TT IgG was equal to $5 \times 10^{-5} \mathrm{IU}$. Specific antibody levels $>2 \mathrm{ng} / \mathrm{ml}$ were considered to be significant.

(a) In vivo anti-TT antibody levels. To determine anti-TT IgG levels in healthy donors after booster, nine subjects were reimmunized. The anti-TT IgG levels in serum ranged from 104 $\mu \mathrm{g} / \mathrm{ml}$ to $242 \mu \mathrm{g} / \mathrm{ml} 2 \mathrm{wk}$ after booster. No significant differences between adult and child controls were noted. In the patient, the serum anti-TT Ab titer was $4 \mu \mathrm{g} / \mathrm{ml}$ before the last booster. The serum $\mathrm{Ab}$ titer rose to $24 \mu \mathrm{g} / \mathrm{ml}$ at 2 wk after this booster. 6 wk after boostering the serum antibody level was $12 \mu \mathrm{g} / \mathrm{ml}$.

(b) In vitro anti-TT Ig synthesis in normal donors. PBMNC from healthy donors were isolated 2, 4, and 6 wk after TT booster and cultured in the presence of TT. The highest Ag and PWM inducible TT specific responses were found at $2 \mathrm{wk}$ and progressively decreased thereafter. Fig. 2 shows the geometric means of anti-TT Ab production 2 wk after immunization in seven control individuals. No correlation between in vitro $\mathrm{Ab}$ synthesis and in vivo $\mathrm{Ab}$ levels was observed. Maximal $\mathrm{Ab}$ concentration in culture supernatants were found using either 1 or $2 \times 10^{6}$ cells $/ \mathrm{ml}$.

In cultures induced with $\mathrm{Ag}$, the IgG peak response was obtained at TT concentration between $1 \mathrm{ng}$ and $50 \mathrm{ng} / \mathrm{ml}$. When TT was present during culture at concentrations $>50 \mathrm{ng} / \mathrm{ml}$, the level of specific $\mathrm{Ab}$ detectable by ELISA began to decline and was virtually absent at concentrations $>1 \mu \mathrm{g} / \mathrm{ml}$. No significant specific IgM production in response to TT was found. PWM also induced Ag-specific IgG production. In addition, minimal quantities of specific IgM were produced.

The specific anti-TT IgG response to PWM was stronger, similar to or lower than the Ag-stimulated response, depending on the donors. Two control donors failed to respond significantly to TT in vitro, despite the in vivo presence of normal levels of TT-specific IgG. In both cases, anti-TT Ab production in re-

Table II. Immunoglobulin Allotypes of the FLTT Subject and His Parents

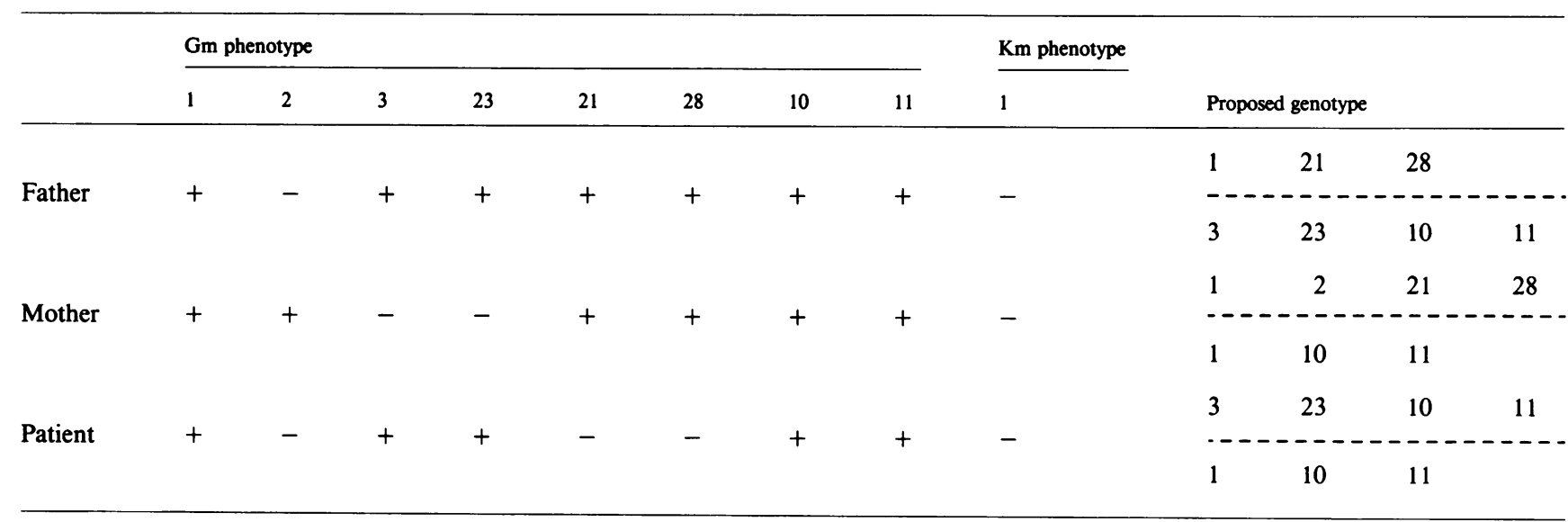




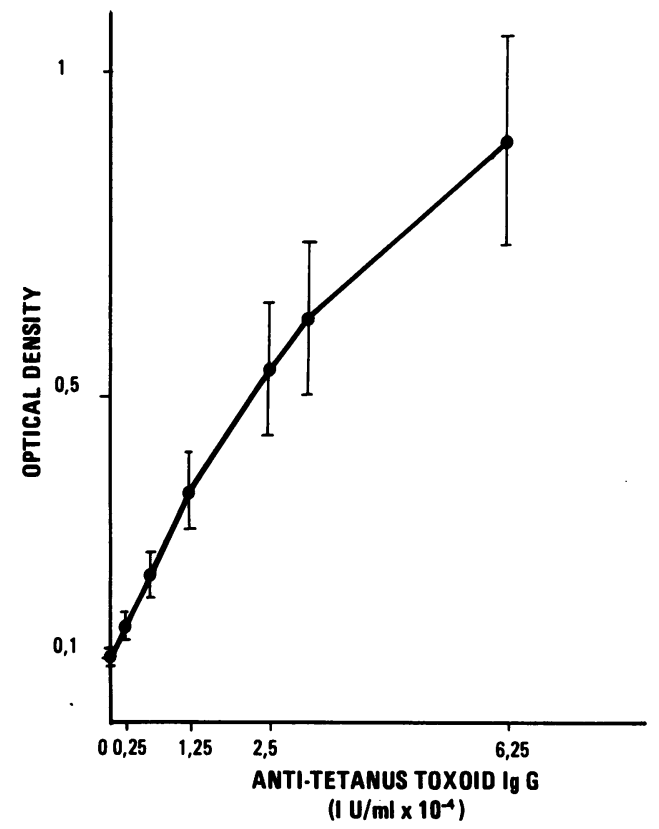

Figure 1. Standard curve for the determination of TT-specific IgG. Dilutions of a standard anti-TT antibody preparation were assayed for specific anti-TT IgG by ELISA. Optical density was measured at 405 $\mathrm{nm}$ after $60 \mathrm{~min}$. Points represent the mean and SD of 25 values.

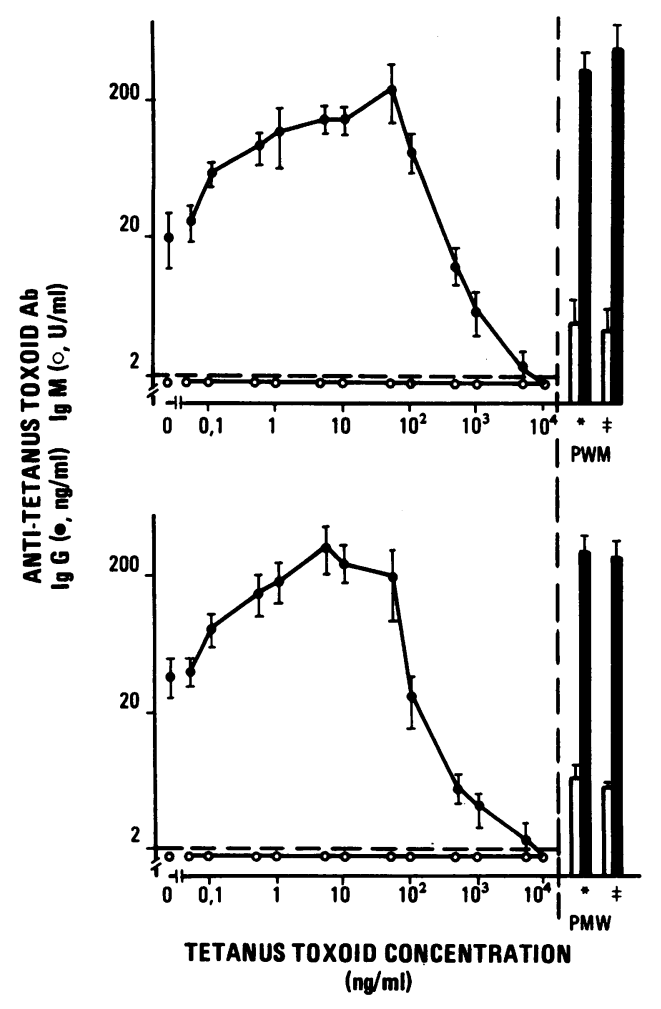

Figure 2. In vitro TT-specific IgG (๑, and closed bars) and IgM (o, and open bars) in normal donors. Antibody production was induced by either TT (line graph) or PWM (bar graph). Cultures were performed in roundbottom tubes at a density of $10^{6}$ cells $(t o p)$ or $2 \times 10^{6}$ cells (bottom) in a volume of $0.5 \mathrm{ml}$. Data are expressed as the geometric means + SEM for duplicate cultures in seven individuals. ${ }^{*} 1 \mu \mathrm{g} / \mathrm{ml} \mathrm{PWM}$. $\ddagger 4 \mu \mathrm{g} / \mathrm{ml}$ PWM. sponse to PWM was present, but very low compared with other donors (threefold less).

Addition of cycloheximide to in vitro cultures inhibited Aginduced $\mathrm{Ab}$ production by $>90 \%$, demonstrating the de novo nature of $\mathrm{Ab}$ synthesis. However, in cultures without $\mathrm{Ag}$, a certain amount of specific $A b$ was present. A portion of this background was due to spontaneous specific antibody synthesis in vitro by cells activated in vivo, since a partial inhibition was induced by cycloheximide.

(c) In vitro anti-TT synthesis in the patient. In vitro antiTT Ab production by patient's PBMNC was measured 2 and 4 wk after the first booster given during this study and 2 and $6 \mathrm{wk}$ after a second booster. In Fig. 3, the in vitro specific anti-TT $\mathrm{Ab}$ production after the first booster is shown. Specific anti-TT IgG synthesis was found after PWM stimulation, but both spontaneous and TT-induced Ab production were completely absent. Similar results were obtained for IgM production (data not shown). At 4 wk postimmunization, the spontaneous and $\mathrm{Ag}$ induced $\mathrm{Ab}$ synthesis were essentially comparable with those found after 2 wk. The small amount of anti-TT IgG and IgM present in cultures induced by PWM was lower than that found at $2 \mathrm{wk}$.

In Fig. 4, the in vitro culture results obtained at 2 and $6 \mathrm{wk}$ after the last immunization are shown. At 2 wk, both a spontaneous and a TT-induced production of specific IgG were observed. The levels of $\mathrm{Ab}$ production and the $\mathrm{Ag}$ dose-response relationship were very similar to those found in the normal control group (Figs. 4 and 2, respectively). The peak specific $A b$ response was obtained at an $\mathrm{Ag}$ concentration of $1 \mathrm{ng} / \mathrm{ml}$, and declined to background levels at $100 \mathrm{ng} / \mathrm{ml}$. The PWM response was similar to that found after the first immunization. $6 \mathrm{wk}$ after booster, $\mathrm{Ab}$ synthesis was still induced by both $\mathrm{Ag}$ and PWM,

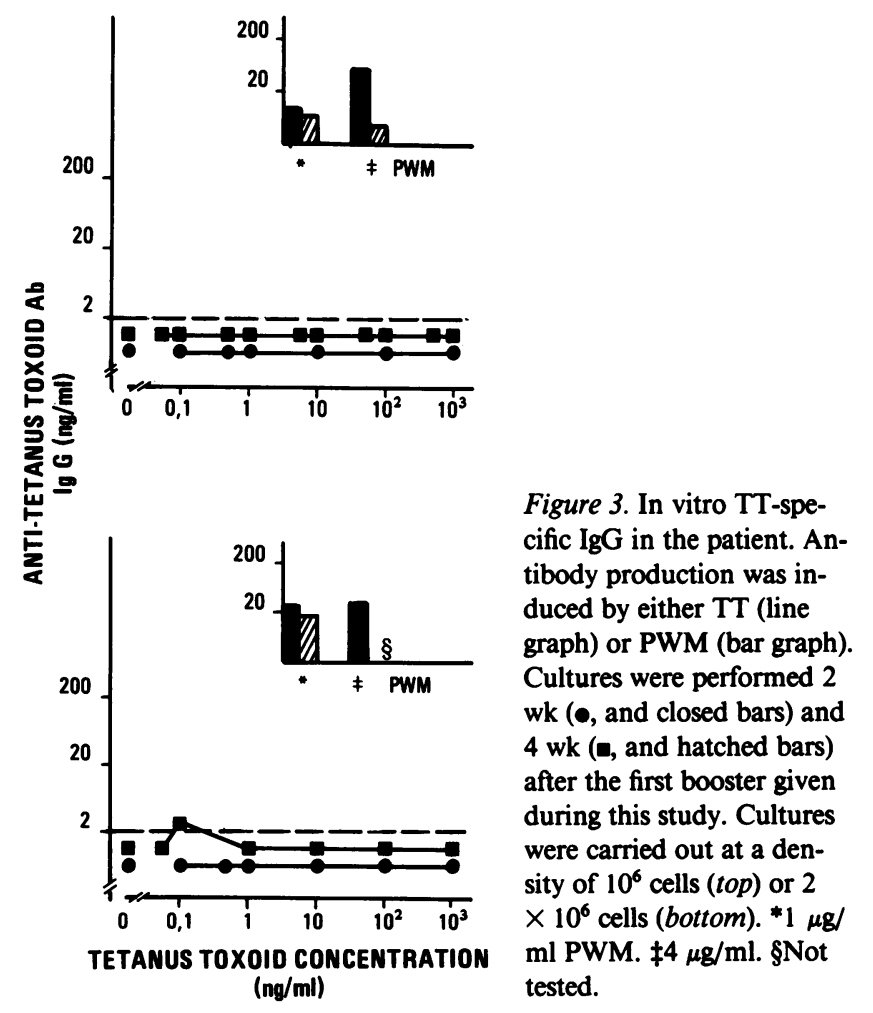




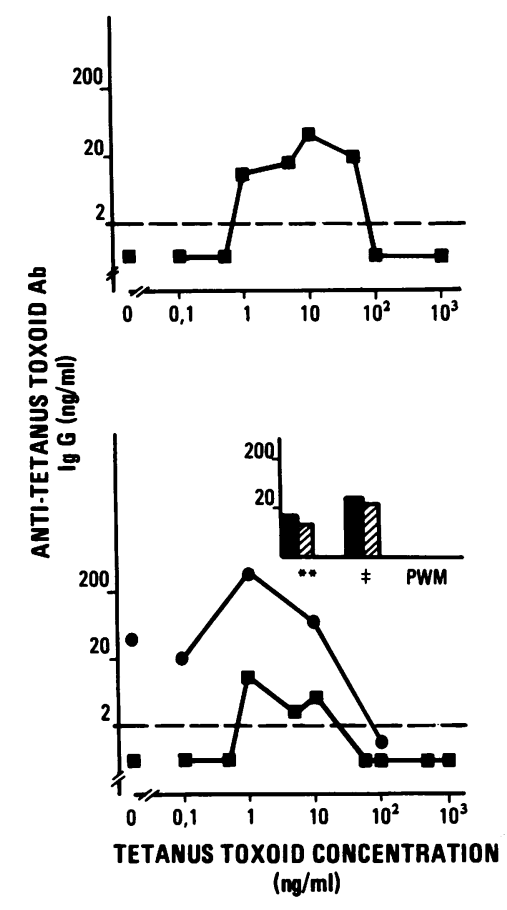

Figure 4. In vitro TT-specific IgG in the patient. Antibody production was induced by either TT (line graph) or PWM (bar graph). Cultures were performed 2 wk (৫, and closed bars) and 4 wk ( $a$, and hatched bars) after the last immunization. Cultures were carried out at a density of $10^{6}$ cells (top) or $2 \times 10^{6}$ cells (bottom). **1 $\mu \mathrm{g} / \mathrm{ml}$ PWM. $\ddagger 4 \mu \mathrm{g} / \mathrm{ml}$ PWM.

but the magnitude of the Ag-induced response was significantly lower than that found at 2 wk. The de novo Ab synthesis was confirmed by the inhibition of $\mathrm{Ab}$ production in cultures containing cycloheximide.

In vitro polyclonal Ig synthesis in the patient and controls To determine whether the anti TT Ab found in cultures stimulated with low concentration of TT (1-50 ng/ml) represented a fraction of a polyclonal response, polyclonal Ig levels were determined by ELISA. Significant polyclonal IgG and IgM production was observed only in cultures with concentrations of $\mathrm{Ag}>1 \mu \mathrm{g} / \mathrm{ml}$. Table III shows pooled data obtained from four normal donors. They demonstrate that at the low concentrations of TT, which induced specific IgG synthesis, no increase in polyclonal Ig levels was detected. The PWM response was variable between donors. Synthesis of polyclonal Ig was observed in all patients' PBMNC cultures that were performed at high antigen concentration (Table III). In cultures carried out 2 wk after the second booster given during the study, at the low TT concentration which induced the highest specific Ab synthesis level, no increase in polyclonal IgG and IgM could be detected. These results indicate that the specific anti-TT $A b$ response obtained at low TT concentrations is a result of Ag-specific interactions between the different cell populations.

\section{Antigen-specific $T$ cell proliferation}

The TT specific proliferative $\mathrm{T}$ cell responses in this patient were also investigated and compared with those of normal donors immunized with TT. The time after booster immunization, at which blood cells were collected, varied between donors. Although high background proliferation was obtained in some experiments, both normal donors and patient lymphocytes presented significant TT-specific proliferative response as shown in Table IV. Stimulation indices ranged from 2.2 to 6. Proliferation generally reached a peak at an $\mathrm{Ag}$ concentration of $10 \mu \mathrm{g} / \mathrm{ml}$.

\section{Discussion}

In the present paper we describe the in vivo and in vitro response to TT in an immunodeficient child transplanted with fetal tissue 7 yr previously. After FLTT, the subject developed a split chimerism. The present HLA phenotype of PBMNC shows that all $\mathrm{T}$ lymphocytes are of donor origin, while $\mathrm{B}$ lymphocytes and monocytes are of host origin. It is of interest that previous HLA typings, performed in a 4-yr period after transplantation, revealed the presence of two monocyte populations, one expressing donor phenotype, and the other expressing recipient phenotype. However, transplant-derived monocytes were found to disappear

Table III. Total Ig Production in Response to TT and PWM

\begin{tabular}{|c|c|c|c|c|c|c|c|c|c|c|}
\hline & \multirow{2}{*}{$\begin{array}{l}\text { Ig } \\
\text { isotype }\end{array}$} & \multicolumn{7}{|c|}{$\mathrm{TT}(n g / m l)$} & \multicolumn{2}{|c|}{ PWM $(\mu g / m l)$} \\
\hline & & 0 & 0.1 & 1 & 10 & $10^{2}$ & $10^{3}$ & $10^{4}$ & 1 & 4 \\
\hline \multirow[t]{2}{*}{ Normal donors* } & G & 1,132 & 1,126 & 1,117 & 1,470 & 2,449 & 2,689 & 4,360 & 8,545 & 8,390 \\
\hline & $\mathbf{M}$ & 1,344 & 1,655 & 1,835 & 3,228 & 4,315 & 6,306 & 11,540 & 14,912 & 16,142 \\
\hline \multirow[t]{2}{*}{ Patient I } & G & 135 & 112 & 90 & - & 200 & 322 & 1,127 & 4,062 & 2,484 \\
\hline & $\mathbf{M}$ & 280 & 330 & 280 & - & 540 & 1,010 & 2,045 & 3,625 & 2,187 \\
\hline \multirow[t]{2}{*}{ Patient $\ddagger$} & G & 153 & 181 & 163 & 153 & 163 & 168 & 245 & 2,468 & 1,859 \\
\hline & $\mathbf{M}$ & 165 & 220 & 335 & 247 & 355 & 605 & 815 & 2,125 & 1,812 \\
\hline \multirow[t]{2}{*}{ Patient II } & G & 2,200 & 2,112 & 2,237 & 2,652 & - & - & 2,550 & 2,075 & 2,850 \\
\hline & $\mathbf{M}$ & 440 & 380 & 495 & 380 & - & - & 650 & 500 & 1,125 \\
\hline \multirow[t]{2}{*}{ Patient $\pi$} & G & 1,643 & 1,829 & 1,725 & 2,038 & 2,617 & - & 3,577 & 4,860 & 5,850 \\
\hline & $\mathbf{M}$ & 186 & 112 & 214 & 187 & 626 & - & 11,139 & 1,587 & 3,013 \\
\hline
\end{tabular}

* Values represent means obtained from four donors. Symbols refer to results obtained at 2 wk (I) and 4 wk ( $\ddagger$ ) after the first immunization given during this study, $2 \mathrm{wk}$ (II), and $6 \mathrm{wk}(\pi)$ after the second immunization. 


\begin{tabular}{|c|c|c|c|c|c|}
\hline & \multirow{2}{*}{$\begin{array}{l}\text { Time interval after } \\
\text { immunization }\end{array}$} & \multicolumn{4}{|c|}{ cpm of $\left[{ }^{3} \mathrm{H}\right]$ thymidine incorporated } \\
\hline & & Medium & $\mathrm{TT}(1 \mu \mathrm{g} / \mathrm{ml})$ & TT $(10 \mu \mathrm{g} / \mathrm{ml})$ & TT $(50 \mu g / m l)$ \\
\hline & $w k$ & & & & \\
\hline Donor 6 & 4 & $14,856 \pm 6,291$ & $18,943 \pm 3,069$ & $32,194 \pm 1,843$ & $26,340 \pm 4,826$ \\
\hline Donor 6 & 20 & $3,755 \pm 320$ & - & $9,300 \pm 380$ & $3,319 \pm 419$ \\
\hline Donor 7 & 2 & $10,535 \pm 1,491$ & $23,698 \pm 3,315$ & $54,501 \pm 2,708$ & $12,539 \pm 4,241$ \\
\hline Donor 8 & 2 & $6,341 \pm 280$ & $11,398 \pm 1,164$ & $38,107 \pm 2,173$ & $11,109 \pm 1,831$ \\
\hline Donor 9 & 20 & $8,268 \pm 477$ & $11,473 \pm 285$ & $24,177 \pm 5,958$ & $21,114 \pm 1,924$ \\
\hline Patient & 20 & $18,442 \pm 5,810$ & - & $74,666 \pm 5,345$ & $8,938 \pm 1,459$ \\
\hline
\end{tabular}

* Values represent means \pm SD for triplicate cultures.

progressively from peripheral blood and were not detectable on many occasions tested in the last $3 \mathrm{yr}$.

Despite persisting engraftment of only $T$ cells, full immunological reconstitution was achieved in the patient. The clinical follow-up demonstrated that this chimeric state did not prevent the occurrence of clinically normal immune responses. The quality and stability of this reconstitution have resulted in good health and normal development during the $7 \mathrm{yr}$ since FLTT. The subject presented a normal defence against pathogenic microorganisms such as fungi, bacteria, and viruses. In addition, he was found to mount a subnormal to normal in vivo $\mathrm{Ab}$ response after vaccination with a variety of viral and bacterial $\mathrm{Ag}$ including TT $(1,9)$.

The results of $\mathrm{Ig}$ allotype determination strongly indicate that $\mathrm{Ab}$ are synthetized by host $\mathrm{B}$ cells. Serum Ig from the patient have an allotype compatible with that found in his parents. The Gm1, 10, 11 allotype, found both in the patient and his mother, is extremely rare in Caucasians (Dr. L. Rivat, personal communication). Therefore, it is unlikely that Ig with this allotype are derived from transplanted B cells. These results eliminate the possibility that $A b$ were synthetized by a small population of donor-derived B lymphocytes that could not be detected by HLA typing.

To determine whether the in vivo $\mathrm{Ab}$ response resulted from cooperation between the patient's cells and donor-derived $T$ cells, the in vitro anti-TT IgM and IgG-specific Ab production by PBMNC was investigated. Results were compared with those obtained in healthy donors.

Specific Ab synthetized by normal individuals were almost completely of IgG isotype and occurred at low Ag concentrations, at which no polyclonal Ig synthesis was observed. At Ag concentrations $>1 \mu \mathrm{g} / \mathrm{ml}$, specific $\mathrm{Ab}$ production was virtually absent. This might result either from the formation of immune complexes or from a suppressive mechanism as it has been observed in in vitro $\mathrm{Ag}$ pulsing experiments (17).

TT was found to induce an increase in total in vitro Ig production when present at high concentrations. A similar observation has been described (12). This could be due to a nonspecific activation of helper $\mathrm{T}$ cells with release of $\mathrm{T}$ cell factors that result in polyclonal $\mathrm{B}$ cell activation. In the patient, in vitro Aginduced $\mathrm{Ab}$ synthesis was observed after the last in vivo booster. In experiments performed after the first immunization given during this study, anti-TT Ab synthesis was detectable only in cultures stimulated by PWM. The spontaneous and Ag-driven synthesis of IgG and IgM were completely absent. This may be attributed to the fact that PWM and TT induce the activation of different populations of cells, and that the frequency of cells able to respond to PWM is higher than that able to respond to Ag. A comparable difference in frequence has been described for antigen-specific precursor $T$ cells by Lane et al. (18). Such a difference may also exist at the level of recirculating memory B cells (19).

The results obtained after the last immunization demonstrate the ability of the patient to synthetize specific $A b$ in response to $\mathrm{TT}$ in vitro after repeated in vivo $\mathrm{Ag}$ stimulation.

2 wk after the last booster, a significant amount of anti-TT Ab was synthesized in vitro after either TT or PWM stimulation. Moreover, the in vitro specific response was still present $6 \mathrm{wk}$ after this immunization. The $\mathrm{Ab}$ synthesis present in vitro was not the result of a polyclonal $B$ cell activation by a nonspecific positive allogeneic effect, since the response was Ag specific (20). In the absence of $\mathrm{TT}$, background specific $\mathrm{Ab}$ production was not significantly different from normal subjects. The Ag doseresponse curve for the patient was comparable with that found in the control group. Involvement of Ag-specific cellular cooperation was further demonstrated by the presence of a TT-induced proliferative response. Additionally, the in vivo and in vitro tolerance observed between donor $T$ lymphocytes and host cells, and the in vitro results obtained after the first in vivo immunization exclude the possibility that our data are due to an allogeneic effect.

Although at present it can not be fully excluded that minor populations of APC and B cells of donor origin are responsible for the immune response observed in this patient, all our data indicate that $\mathrm{T}$ cells of donor origin, which are present in the circulation of a recipient of a mismatched FLTT, appear to recognize TT Ag in association with $D$ region encoded determinants of host origin. This observation is in contrast to the conclusions drawn by other investigators (21-23) who have predicted that in such cases there would be a low or absent interaction of donor T lymphocytes with various cells of the HLA-mismatched host, and consequently a full reconstitution was unexpected. However, Chu et al. (24), recently described a human bone marrow chimera in whom haplotype mismatched donor $T$ cells could cooperate 
with recipient monocytes resulting in proliferative response to $\mathrm{Ag}$ (24). Here we show that cell cooperation occurs in a situation in which HLA incompatibility is apparently complete. Ab was produced despite the absence of determinants shared by donorderived $T$ lymphocytes and recipient cells at the HLA A, B, C, and DR loci. These data, in addition to the previously documented $T$ cell functions of the chimeric child (1) have led us to postulate that the patient's $T$ lymphocytes recognize antigens in association with allogeneic HLA determinants; we have designated this phenomenon the "Allo $+X$ " recognition (1). According to this concept, a variety of cells of the $T$ lineage develop in the thymus, some with self HLA recognition, others with allo HLA recognition. In normal individuals, the former cells are much more frequent and the latter are barely detectable. In sustained HLA mismatched chimeras, persistent stimulation of donor-derived lymphocytes results in expansion of this population, which then develop the full repertoire of $\mathrm{Ag}$ recognition in association with the allogeneic HLA determinants of the host.

Slow immunological reconstitution after transplant could be explained by the time required for clonal expansion of $\mathrm{T}$ cells which recognize allogeneic HLA determinants. It is possible that this population of cells, able to recognize Allo $+\mathrm{Ag}$ can not readily reach the same size as that of cells programmed to recognize Self $+\mathrm{Ag}$. The resulting quantitative difference may account for the requirement of a repeated in vivo $\mathrm{Ag}$ stimulation for the induction of optimal $\mathrm{Ab}$ production in vitro. This interpretation is supported by results obtained from both the murine and human systems $(25,26)$, which demonstrate the existence of both self and allo-restricted $\mathrm{T}$ cell precursors in the normal $T$ cell repertoire. The final restricted recognition expressed by circulating cells may simply result from selection between cells with predetermined restriction specificity. Further studies to confirm this hypothesis are now under progress by investigating the interactions of host TT-specific B cell lines, as APC, with donor TT-specific $\mathrm{T}$ cell clones.

Moreover, at present we can not exclude the possibility that other D region determinants (27) are shared by donor and host cells, enabling cooperation to occur between these apparently totally mismatched cells.

In summary, we observed an in vivo and in vitro production of anti-TT Ab in a chimeric patient in which all detectable $T$ cells are of donor origin and all $B$ cells and monocytes are of host origin. Ab are synthetized by the host B cells. The ability of donor $\mathrm{T}$ cells to cooperate with recipient $\mathrm{B}$ cells and monocytes, resulting in a specific $\mathrm{Ab}$ production against a thymusdependent $\mathrm{Ag}$, suggest the existence of $\mathrm{T}$ lymphocytes bearing recognition structures for Allo $+\mathrm{Ag}$. That such $\mathrm{T}$ cells have not been identified in normal individuals but are found in long-term chimeras suggests that, from an initially low frequency, these cells can be expanded by chronic stimulation.

\section{Acknowledgments}

Our thanks to Dr. H. Betuel for HLA typing, and to Dr. L. Rivat for allotypes determinations. We also wish to express our gratitude to Dr. N. Lydon for his helpful comments and suggestions, to Dr. J. de Vries for reviewing this manuscript, to Miss C. Peronne for technical assistance, and to Mrs. M. Vatan and Miss S. Chevalier for secretarial assistance.

Dr. Roncarolo is the recipient of a Clinical Scientist Award from the Italian "G. Ghirotti" Association.

\section{References}

1. Touraine, J. L. 1983. Bone-marrow and fetal-liver transplantation in immunodeficiencies and inborn errors of metabolism: lack of significant restriction of T-cell function in long-term chimeras despite HLAmismatch. Immunol. Rev. 71:103-121.

2. Unanue, E. R. 1984. Antigen-presenting function of the macrophage. In Annual Review of Immunology. W. E. Paul, C. G. Fathman, and $\mathrm{H}$. Metzger, editors. Annual Reviews Inc., California. 395-428.

3. Howie, S., and W. H. Mc Bride. 1982. Cellular interactions in thymus-dependent antibody responses. Immunol. Today. 3:273-278.

4. Singer, A., and R. J. Hodes. 1983. Mechanisms of T cell-B cell interaction. In Annual Review of Immunology. W. E. Paul, C. G. Fathman, and H. Metzger, editors. Annual Reviews Inc., California. 211241.

5. Matzinger, P. 1981. A one-receptor view of T-cell behaviour. Nature (Lond.). 292:497-501.

6. Janeway, C. A. 1982. The selection of self-MHC recognizing T lymphocytes: a role for idiotypes? Immunol. Today. 3:261-266.

7. Hunig, T., and M. J. Bevan. 1980. Self $\mathrm{H}-2$ antigens influence the specificity of alloreactive cells. J. Exp. Med. 151:1288-1298.

8. Thorsby, E. 1984. The role of HLA in T cell activation. Hum. Immunol. 9:1-7.

9. Touraine, J. L., and H. Betuel. 1981. Immunodeficiency diseases and expression of HLA antigens. Hum. Immunol. 2:147-153.

10. Brenner, M. K., and M. E. North. 1983. Human B cell growth factors overcome $T$ cell-mediated inhibition of specific antibody production: a possible mechanism for the exacerbation of autoimmune disease. Clin. Exp. Immunol. 52:635-640.

11. Geha, R. S. 1981. Dynamics of human circulating antigen reactive cells following secondary immunization with tetanus toxoid. Clin. Immunol. Immunopathol. 19:196-205.

12. Volkman, D. J., S. P. Allyn, and A. S. Fauci. 1982. Antigeninduced in vitro antibody production in humans: tetanus toxoid-specific antibody synthesis. J. Immunol. 129:107-112.

13. Rivat, L., D. Gilbert, and C. Ropartz. 1973. Immunoglobulin allotypic specificities in mixed leucocyte cultures. Immunology. 24:10411049.

14. Betuel, H., L. Gebuhrer, J. Lambet, A. C. Freidel, and A. Farre. 1983. A possible new HLA-DR allele. Hum. Immunol. 8:227-237.

15. Betuel, H., L. Mazet, A. Ehrsam, J. L. Touraine, and J. Traeger. 1980. Detection of anti-monocyte antibodies after kidney transplantation. In Transplantation and Clinical Immunology, Vol. XI. J. L. Touraine, J. Traeger, H. Betuel, J. Brochier, J. M. Dubernard, J. P. Revillard, and R. Triau, editors. Excepta Medica, Amsterdam. 317.

16. Touraine, J. L., and H. Betuel. 1981. Immunodeficiency disease and expression of HLA antigens. Hum. Immunol. 2:147-153.

17. Benveniste, E., and R. H. Stevens. 1983. T suppressor cells are required for the maintenance of the antigen-induced $\mathrm{B}$-cell unresponsive state in humans. Clin. Immunol. 3:166-172.

18. Lane, H. C., G. Whalen, and A. S. Fauci. 1983. Antigen induced human $\mathrm{T}$ cell help: precursor frequency, radiation sensitivity, and allogeneic effects. J. Clin. Invest. 72:636-647.

19. Callard, R. E., G. W. Mc Caughan, J. Babbage, and R. L. Souhami. 1982. Specific in vitro antibody responses by human blood lymphocytes: apparent non responsiveness of PBL is due to a lack of recirculating memory B cells. J. Immunol. 123:153-156.

20. Lanzavecchia, A., B. Parodi, and F. Celada. 1983. Activation of human B lymphocytes: frequency of antigen-specific B cells triggered by alloreactive or by antigen-specific T cell clones. Eur. J. Immunol. 13:733-738.

21. Katz, D. H., T. Hamaoka, and B. Benacerraf. 1973. Cell interactions between histoincompatible $T$ and B lymphocytes. II. Failure of physiologic cooperative interactions between $\mathrm{T}$ and $\mathrm{B}$ lymphocytes from 
allogeneic donor strains in humoral response to hapten-protein conjugates. J. Exp. Med. 137:1405-1418.

22. Thorsby, E., O. J. Bergh, B. Bergholtz, E. Berle, and H. Hirschberg. 1980. HLA restriction of $T$ lymphocyte immune responses: implications for cell replacement therapy of immunodeficiencies. In Fetal Liver Transplantation: Current Concepts and Future Directions. G. Lucarelli, T. M. Fliedner, and R. P. Gale, editors. Excepta Medica, Amsterdam. 134-153.

23. Zinkernagel, R. M., G. N. Callahan, A. Althage, S. Cooper, P. A. Klein, and J. Klein. 1978. On the thymus in the differentiation of "H-2 self-recognition" by T cells: evidence for dual recognition? J. Exp. Med. 147:882-896.

24. Chu, E., D. Umetsu, F. Rosen, and R. S. Geha. 1983. Major histocompatibility restriction of antigen recognition by $T$ cells in a re- cipient of haplotype mismatched human bone marrow transplantation. J. Clin. Invest. 72:1124-1129.

25. Ishii, N., C. N. Baxevanis, Z. A. Nagy, and J. Klein. 1981. Responder $\mathrm{T}$ cells depleted of alloreactive cells react to antigen presented on allogeneic macrophages from nonresponder strains. J. Exp. Med. 9:978-982.

26. Mitchell, D. M., P. C. L. Beverley, D. G. Boyle, L. A. Winger, and R. E. Callard. 1983. Accessory cell and HLA compatibility requirements for the generation of specific in-vitro antibody responses to influenza virus by human blood lymphocytes. Immunology: 50:239-250.

27. Gonwa, T. A., L. J. Picker, H. V. Raff, S. M. Guyert, J. Silver, and J. D. Stobo. 1983. Antigen-presenting capabilities of human monocytes correlates with their expression of HLA-DS, an Ia determinant distinct from HLA-DR. J. Immunol. 130:706-711. 